\title{
Particulate suspended matter $\left(\mathrm{PM}_{10}\right)$, Particulate suspended matter $\left(\mathrm{PM}_{2.5}\right)$, and its Effects on Human Health in NFL Vijaipur Guna M.P.
}

\author{
Mohini Karaiya \\ M.E.StudentEnvironmental Engineering, Civil Engineering Department, \\ Jabalpur Engineering College, Jabalpur \\ R. G. P. V. University, Bhopal, India \\ D.C. Rahi \\ Asst. professor, Civil Department, Jabalpur Engineering College, Jabalpur \\ R. G. P. V. University, Bhopal, India
}

\begin{abstract}
Air pollution data is obtained from a number of fixed site monitors located throughout the study region. These monitors measure backgroundpollution levels at a number of time intervals throughout the day and adaily average is typically calculated for each site. A number of pollutants are measured including, particulate matter $\left(\mathbf{P M}_{2.5}\right.$ and $\left.\mathbf{P M} \mathbf{M}_{10}\right)$. N.F.L. Vijaipur is nitrogenous fertilizer plant producing urea on high unit. With the commencement of commercial production of the Expansion project the gas based unit at Vijaipur now comprises of two 1520 ton per day Ammonia streams and four 1310 ton per day Urea streams and related off-site facilities. The level of $\mathbf{P M}_{10}$ in summer time is noticeable higher than in winter time. The number of respiratory cases varies with the increases of air pollution $\left(\mathbf{P M}_{10} / \mathbf{P M}_{2.5}\right)$ and the changes between winter and summer time. To overcome this pollution my suggestion to N.F.L. Vijaipur that employees should use public transport at the time of office.
\end{abstract}

Keywords: Particulate Suspended Matter $\mathbf{P M}_{10}$ and $\mathbf{P M}_{2.5}$ and N.F.L. as National Fertilizer Limited.

\section{INTRODUCTION}

N.F.L. (National Fertilizer Limited- a Govt. of India Undertaking) is India's highest producer of nitrogenous fertilizers. The company has four plants which are located at Nangal and Bathinda in Punjab Panipat in Haryana and Vijaipur in M.P. N.F.L. Vijaipur project is located in Guna district of Madhya Pradesh (35 Kilometres from Guna). It is spread over 1250 acres of lush green landscaped area comprising the factory area of 650 acres and the township which is spread in an area of 600 acres. The township is inhibited by approx. 6000 people. The factory area consists of various plants like Ammonia (I\&II), Urea(I\&II), Captive Power, DM, Cooling Towers (Urea \& Ammonia), BioFertilizer, Bagging, Pre-Treatment and Effluent Treatment plants in addition to Office buildings, Administration building, Conference halls, Fire Station, Canteens, Product handling conveyors, Urea Storage Silo (I\&II).

Particulates are the complex mixture of multi component particles where size distribution, composition and morphology can vary significantly in space and time. Atmospheric aerosol size ranges from a few nanometres to tens of micrometres. Major component of particulates includes nitrates, sulphates, trace elements, organic material, soot and crustal components.

Air with dust enters in the sampler through circular omni directional inlet reaches to $\mathrm{PM}_{10}$ impactor where all particles having size more than 10 micron are retained. Now air with particles having size less than 10 microns further proceed and pass through WINS impactor which is in well-shaped impactor. A filter dipped in impaction oil is kept in the well where particles hit at specific velocity (maintained by top critical hole of WINS Impactor) this results separation of particles above 2.5 micron to 10 micron. Only particles having size 2.5 micron and below proceed further with air stream and accumulated on PTFE (Poly-tetra fluro-ethylene) membrane filter. 
In India particulates are one of the major pollutants. The finer fraction (up to 2.5 micron) is known to impact human health critically. It is now well established that dust having size more than 10 microns in general do not reach in vital respiratory system. Thus it causes impact only on skin, eyes and soiling of clothes and surfaces.

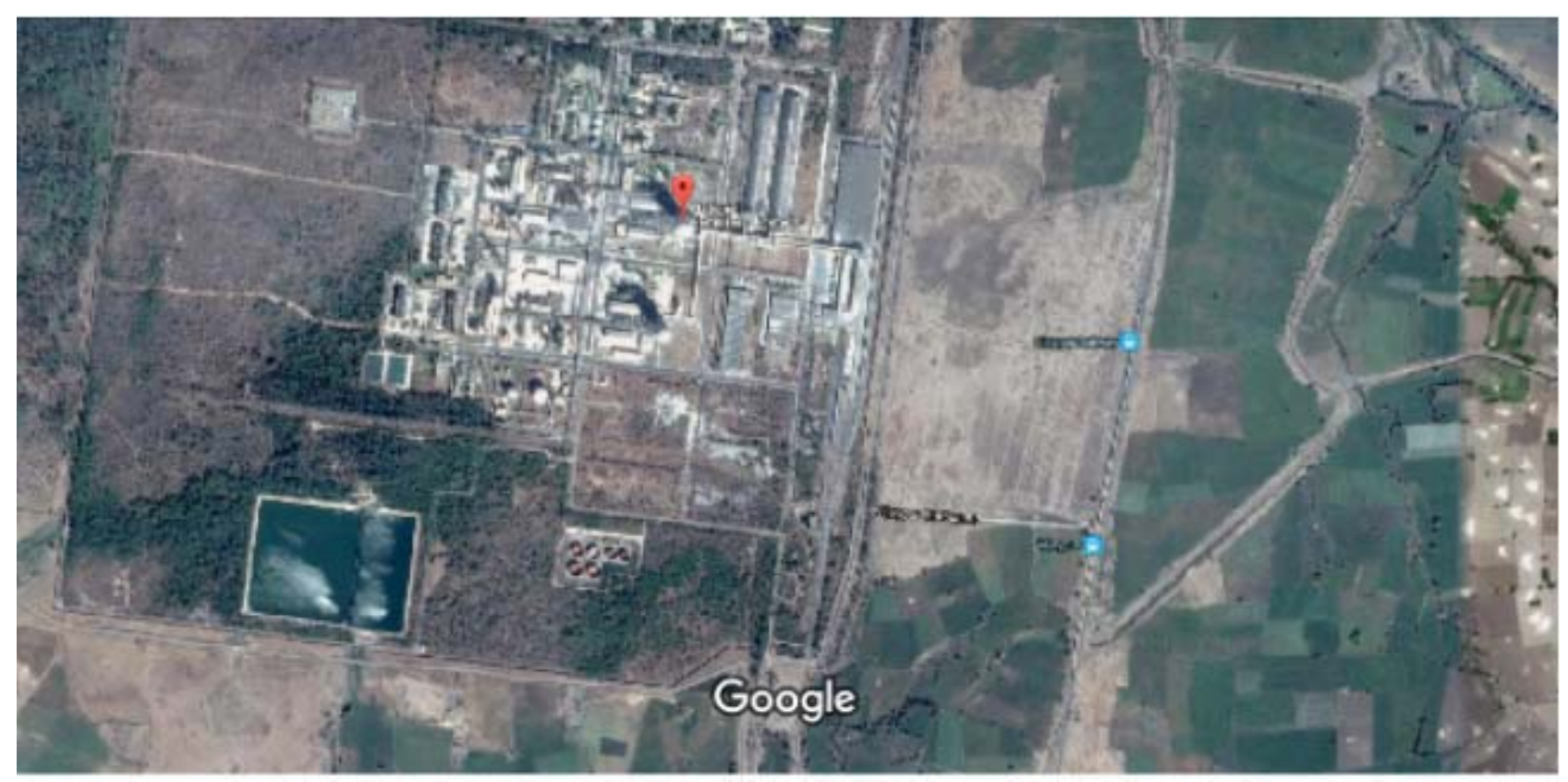

Figure1. GIS map of the sampling location.

\section{EXPERIMENTAL WORK}

For the purpose of this study $\mathrm{PM}_{10}$ and $\mathrm{PM}_{2.5} \mathrm{I}$ have taken three different station or spot to compare the pollution at different season in N.F.L. Vijaipur Guna in M.P. using Ecotech AAS 127MFC. If PM $_{10}$ monitoring are needed, then only WINS Impactor should not be fitted in the instrument. The results obtained are tabulated as below. 

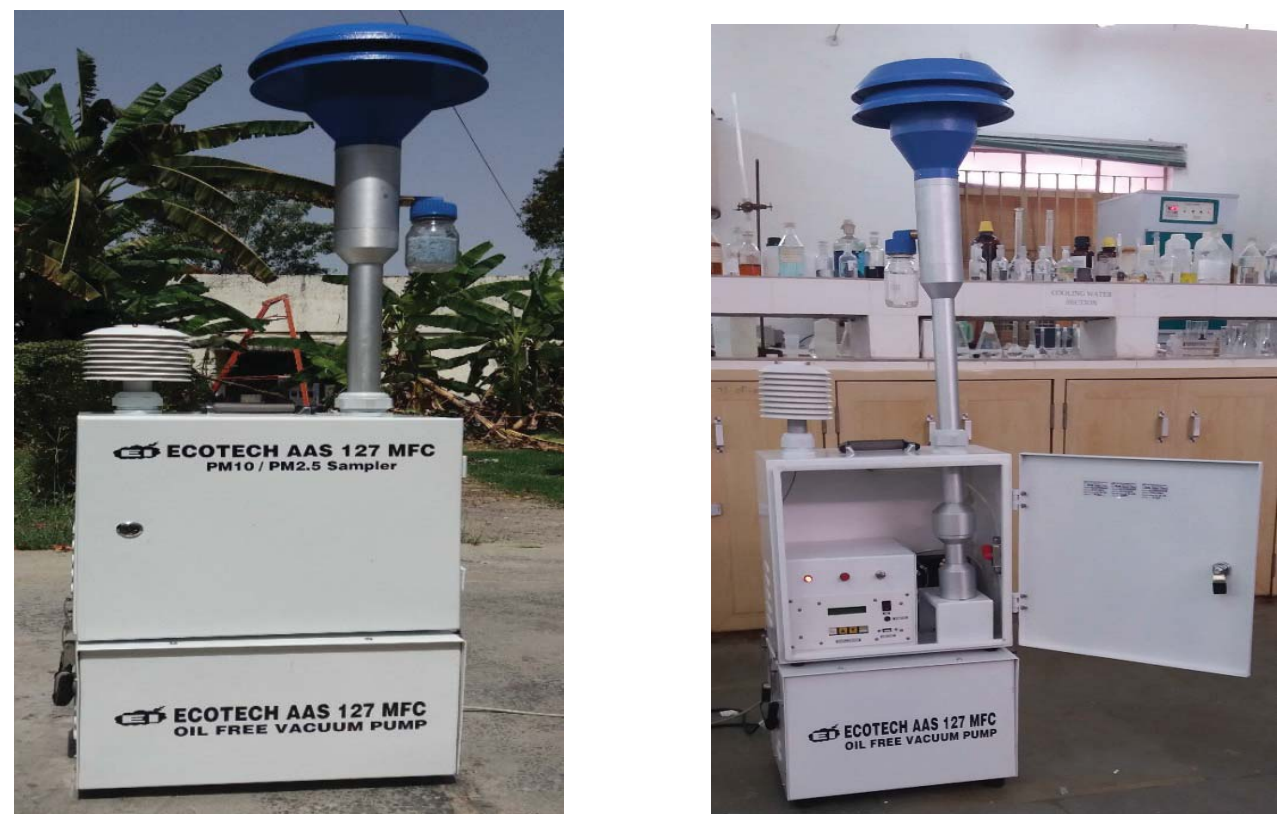

\section{RESULTS AND DISCUSSION}

Computation of Mass Concentration: Compute the average mass concentration (MC) of $\mathrm{PM}_{10} / \mathrm{PM}_{2.5}$ during the sampling period using the following formula with the information assembled data.

$$
\mathrm{MC}=\frac{P W \times P^{\mathrm{a}}}{\mathrm{y}}
$$

Where:

$\mathrm{DW}=$ The net change in the mass $(\mathrm{g})$ of the $47 \mathrm{~mm}$ PTFE membrane filter between the pre collection weighing and the post collection weighing.

$10^{6}=$ Conversion factor from grams $(\mathrm{g})$ to $\operatorname{micrograms}(\mu \mathrm{g})$.

$\mathrm{V}=$ The volume $\left(\mathrm{m}^{3}\right)$ drawn through the filter.

Table1. Rainy Season: July 2015

\begin{tabular}{|l|l|l|}
\hline Stations & $\mathrm{PM}_{10}\left(\mathrm{in} \mu \mathrm{g} / \mathrm{m}^{3}\right)$ & $\mathrm{PM}_{2.5}\left(\mathrm{in} \mu \mathrm{g} / \mathrm{m}^{3}\right)$ \\
\hline Central Lab & 34 & NIL \\
\hline Cooling Tower & 89 & 50 \\
\hline Bio/TEP Area & 75 & 40 \\
\hline
\end{tabular}




\begin{tabular}{|l|l|l|}
\hline Stations & $\mathrm{PM}_{10}\left(\right.$ in $\left.\mu \mathrm{g} / \mathrm{m}^{3}\right)$ & $\mathrm{PM}_{2.5}\left(\right.$ in $\left.\mu \mathrm{g} / \mathrm{m}^{3}\right)$ \\
\hline Central Lab & 34 & NIL \\
\hline Cooling Tower & 89 & 50 \\
\hline Bio/TEP Area & 75 & 40 \\
\hline
\end{tabular}

Table2. Winter Season: November 2015

\begin{tabular}{|l|l|l|}
\hline Stations & $\mathrm{PM}_{10}\left(\mathrm{in} \mu \mathrm{g} / \mathrm{m}^{3}\right)$ & $\mathrm{PM}_{2.5}\left(\mathrm{in} \mu \mathrm{g} / \mathrm{m}^{3}\right)$ \\
\hline Central Lab & 74 & 36 \\
\hline Cooling Tower & 68 & 40 \\
\hline Bio/TEP Area & 72 & 38 \\
\hline
\end{tabular}

December 2015

\begin{tabular}{|l|l|l|}
\hline Stations & $\mathrm{PM}_{10}\left(\right.$ in $\left.\mu \mathrm{g} / \mathrm{m}^{3}\right)$ & $\mathrm{PM}_{2.5}\left(\right.$ in $\left.\mu \mathrm{g} / \mathrm{m}^{3}\right)$ \\
\hline Central Lab & 76 & 40 \\
\hline Cooling Tower & 70 & 35 \\
\hline Bio/TEP Area & 71 & 38 \\
\hline
\end{tabular}

Table3. Summer Season: May 2016

\begin{tabular}{|l|l|l|}
\hline Stations & $\mathrm{PM}_{10}\left(\mathrm{in} \mu \mathrm{g} / \mathrm{m}^{3}\right)$ & $\mathrm{PM}_{2.5}\left(\mathrm{in} \mu \mathrm{g} / \mathrm{m}^{3}\right)$ \\
\hline Central Lab & 89 & 50 \\
\hline Cooling Tower & 90 & 54 \\
\hline Bio/TEP Area & 77 & 46 \\
\hline
\end{tabular}


June 2016

\begin{tabular}{|l|l|l|}
\hline Stations & $\mathrm{PM}_{10}\left(\right.$ in $\left.\mu \mathrm{g} / \mathrm{m}^{3}\right)$ & $\mathrm{PM}_{2.5}\left(\mathrm{in} \mu \mathrm{g} / \mathrm{m}^{3}\right)$ \\
\hline Central Lab & 90 & 52 \\
\hline Cooling Tower & 92 & 55 \\
\hline Bio/TEP Area & 78 & 47 \\
\hline
\end{tabular}

\section{CONCLUSION}

The most important finding is: (i) In generally, $\mathrm{PM}_{10}$ and $\mathrm{PM}_{2.5}$ concentration (24hours) of six months (May, June, July, August, November and December) in research area is within municipal guidelines $\left(100 \mu \mathrm{g} / \mathrm{m}^{3}\right.$,24hours), and it varies with the change of seasons. From an above results I conclude that level of PM10 in summer time is noticeable higher than in winter time. (ii) The number of respiratory cases varies with the increases of air pollution $\left(\mathrm{PM}_{10} / \mathrm{PM}_{2.5}\right)$ and the changes between winter and summer time. To overcome this pollution my suggestion to N.F.L. Vijaipur that employees should use public transport at the time of office. Due to more vehicle's used in township and factory too much pollution is occurring. Sometimes pollution control at source is not possible by preventing the emission of pollutants. Then it becomes necessary to install pollution control equipment to remove the gaseous pollutants from main gas stream. The pollutants are present in high concentration at the source and as their distance from the source increases they become diluted by diffusing with environmental air. Pollution control equipment to be used are wet collectors scrubbers gravitational settling cyclone separators and fabric filters.

\section{REFERENCES}

[1] BIS Method IS 5182 (Part 12):2006 USEPA Method TO-13.

[2] BIS Method IS 5182 (Part 23):2006.

[3] Book of Air pollution by MN Rao.

[4] Environmental, health and safety Guideline foundries.

[5] Environmental Protection Agency, Air Pollutants and Global Effects.

[6] Environmental Protection Agency, Effects of Air Pollutants - Health Effects 2012.

[7] Operation Manual of $\mathrm{PM}_{10} / \mathrm{PM}_{2.5}$ Sampler Ecotech Model AAS $127 \mathrm{MFC}$.

[8] Guidelines for the Measurement of Ambient Air Pollutants (NAAQS 2009) (C) Central Pollution Control Board, 2011. 